\title{
Three new species of Cladonia (Cladoniaceae, Ascomycota) from Southern Brazil
}

\author{
ANA M. CHARNEI ${ }^{1}$, SIONARA ELIASARO ${ }^{1}$ and EMERSON L. GUMBOSKI ${ }^{2}$ \\ ${ }^{1}$ Universidade Federal do Paraná, Campus Politécnico, Setor de Ciências Biológicas, Departamento de Botânica, \\ Av. Cel. Francisco H. dos Santos, s/n, Jardim das Américas, 81531-980 Curitiba, PR, Brasil \\ ${ }^{2}$ Universidade Federal do Rio Grande do Sul, Campus do Vale, Instituto de Biociências, \\ Departamento de Botânica, Av. Bento Gonçalves, 9500, 91501-970 Porto Alegre, RS, Brasil \\ Manuscript received on November 5, 2013; accepted for publication on April 3, 2014
}

\begin{abstract}
Cladonia maculata, C. paranaensis and C. quiririensis are described as new to science. These species were found between the altitudes of 900 to 1887 meters on the Serra do Mar Mountain in Southern Brazil.
\end{abstract}

Key words: Lichen, Paraná, Santa Catarina, Serra do Mar, taxonomy.

\section{INTRODUCTION}

The Serra do Mar is a mountain range which extends, parallel to the Atlantic coastline, for about $1000 \mathrm{~km}$ from the states of Rio de Janeiro to Santa Catarina (Santos 2004). In the Southern Brazil, it comprises a chain of mountains with peaks higher than $1800 \mathrm{~m}$ of altitude in the state of Paraná. In the northern region of the state of Santa Catarina, it ceases to exist as a orographic unit and becomes a parallel strand of mountains and isolated hills (Almeida and Carneiro 1998). Even though the Cladonia P. Browne species are very abundant and diverse in environments above $900 \mathrm{~m}$ in the Serra do Mar in South Brazil, they are still poorly studied. The only references were made by Ahti (2000) and Charnei and Eliasaro (2013). During a survey on Cladoniaceae in this area, where 858 specimens were analyzed we discovered three new species of this genus.

Correspondence to: Ana Marcia Charnei

E-mail: acharnei@yahoo.com.br

\section{MATERIALS AND METHODS}

The new species are described from specimens collected on soil or rock in high-altitude grassland vegetation between 900 to $1887 \mathrm{~m}$ on the Serra do Mar Mountain range in South Brazil (Figure 1). The geographic and climatic data from the study area are described in Charnei and Eliasaro (2013).

The specimens were examined using standard stereoscopic and light microscopic techniques. Sections of thalli and picnidia were mounted in water. Chemical constituents were identified by spot tests, under UV light (Taylor 1967, 1968) and thin layer chromatography using $\mathrm{C}$ solvent system (Culberson and Ammann 1979, Elix and ErnstRussell 1993).

\section{RESULTS AND DISCUSSION}

Cladonia maculata Charnei, Eliasaro and Gumboski, sp. nov. (Figures 2A-B)

MycoBank MB 807910 


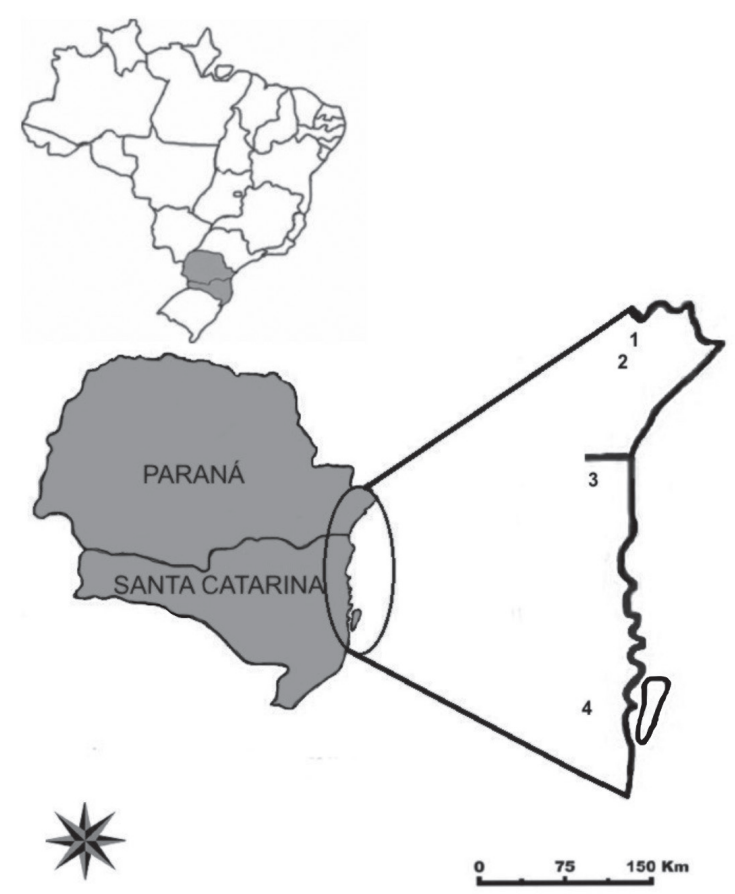

Figure 1 - 1- Map of the study area with the collection localities of the new species: 1- Serra do Ibitiraquire; 2- Serra da Graciosa; 3- Serra do Quiriri; 4- Serra do Tabuleiro.

Differing from Cladonia secundana by the medulla of primary squamules and podetia with orange pigment, and by the podetia without stereome and with a surface markedly maculate.
TYPE

- BRAZIL. State of Santa Catarina: Municipality of Santo Amaro da Imperatriz, Pico da Serra do Tabuleiro, 2749's, 48 $53^{\prime} \mathrm{W}, 1250 \mathrm{~m}, 13$ August 2011, A. M. Charnei et al. 325 (Holotype UPCB).

\section{ETYMOLOGY}

The specific epithet is derived from the Latin word macula $(=$ spot $)$ and refers to the maculate podetia.

\section{DESCRIPTION}

Primary thallus: persistent, consisting of lobed squamules, generally ascending, $0.1-1.0 \mathrm{~cm}$ long $\times 0.2-1.3 \mathrm{~cm}$ wide, soredia and granules absent, margins entire to irregularly crenate, without rhizines; upper surface corticate, yellowish green, verruculose, slightly glossy, pruine absent; lower surface ecorticate, orange to brownish, arachnoid, not veined; cortex 80-240 $\mu \mathrm{m}$ thick; medulla 110 $320 \mu \mathrm{m}$ thick, mainly orange to rarely white with orange spots; pycnidia abundant, mainly laminal, red to brownish red, pyriform, red mucilage; conidia falciform, 7-8 $\times 1 \mu \mathrm{m}$. Secondary thallus: $0.2-2.1 \mathrm{~cm}$ tall, $0.7-1.5 \mathrm{~mm}$ thick, yellowish green to olive green, simple to often moderately branched
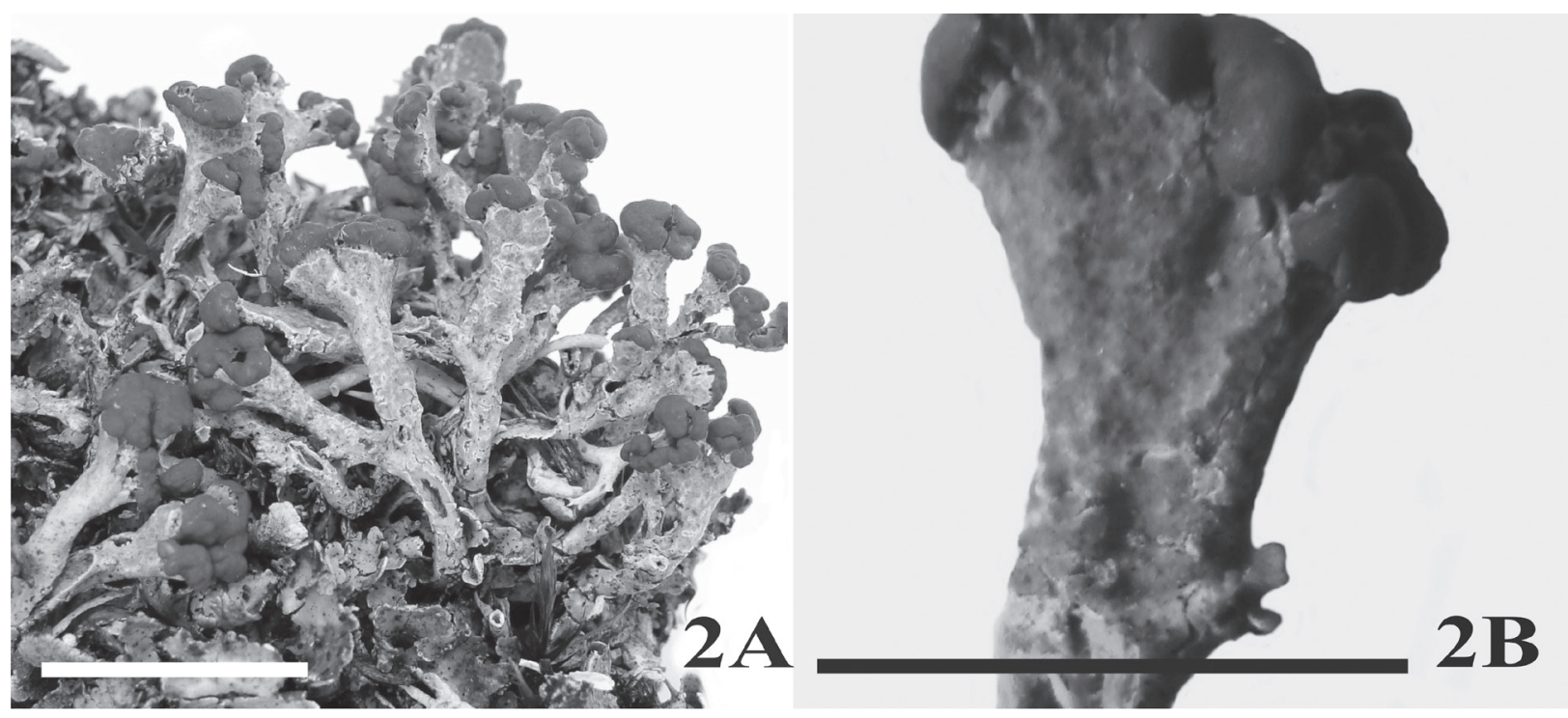

Figure 2 - Cladonia maculata. A- General aspect. B- Detail of macula (A. M. Charnei et al. 325). 
in upper regions of podetia, imperforate, but sometimes the hymenial disks break up, ascyphose, not melanotic at base; surface corticate, maculate, distinct, macula up to $1.2 \mathrm{~mm}$ long, verruculose and cracked, soredia and granules absent, squamules lobed, up to $0.6 \mathrm{~mm}$ long, scarce; cortex (0-) 50$140 \mu \mathrm{m}$ thick; medulla $250-550 \mu \mathrm{m}$ thick, mainly orange to rarely white with orange spots; stereome absent; central canal felty; hymenial discs common, red, apical, solitary or clustered, with up to $0.4 \mathrm{~cm}$ in diameter when solitary but smaller when clustered; ascospores ellipsoid, 9-12 $\times 4 \mu \mathrm{m}$; pycnidia absent.

CHEMISTRY

Spot tests: cortex K-, C-, KC-, UV-; medulla K+ brownish red, C-, UV-. TLC: usnic and rhodocladonic acids, and three unidentified substances with Rf C approximately 13, 35 and 40.

\section{ECOLOGY AND DISTRIBUTION}

Cladonia maculata is known only from the type locality in the Pico da Serra do Tabuleiro, a region in the Southeast part of the state of Santa Catarina, where it is common and grows on the soil and on a thin layer of sediment on rock, in open and very exposed sites at $1250 \mathrm{~m}$, commonly growing with Cladia aggregata (Sw.) Nylander (1876: 88).

\section{REMARKS}

Cladonia maculata is distinguished by the broad primary squamules, with orange (rarely white with orange spots) medulla, the podetia distinctly maculate (Figure 2B) without stereome and by the production of usnic and rhodocladonic acids.

Cladonia maculata is similar to C. secundana Nylander (1874: 71), a species that has chemotypes with usnic and rhodocladonic acids (Ahti 2000), by having a persistent primary thallus, consisting of lobed squamules and corticate podetia. However, C. secundana differ in having a completely white medulla, and podetia emaculate with a continuous to subcontinuous stereome (Stenroos 1989, Ahti
2000). These two species grow together in the Serra do Tabuleiro, where they can be easily differentiated by observing the podetial surface.

This species is clearly a member of Cladonia miniata group (Stenroos 1989) by the persistent primary thallus, consisting of broad squamules with thick cortex and by the red hymenial discs. Within this group, due to the color of the medulla and absence of stereome, C. maculata could be mistaken for C. miniata G. Meyer. (1825: 149) and C. salmonea S. Stenroos (1989: 255). However, in C. miniata the primary squamules have granules at the margins and a veined lower surface, the podetium is flabellate, poorly differentiated from primary squamules and also differs chemically since it lacks usnic acid (Ahti 2000). Cladonia salmonea has elongated squamules deeply divided into lobes, up to $5.0 \mathrm{~cm}$ long, which are greater than those found in C. maculata and the podetia, that are rarely produced, are very rudimentary and deformed with no more than $2.0 \mathrm{~mm}$ in height (Stenroos 1989, Ahti 2000), whereas in C. maculata they are frequent and taller. Furthermore, in these two species the surfaces of podetia are emaculate (Stenroos 1989, Ahti 2000).

Cladonia parvipes (Vain.) S. Stenroos (in Ahti 2000: 221), another member of Cladonia miniata group, can be distinguished by its squamules with granules at the margins, the podetial surface partially ecorticate and emaculate and by the absence of usnic acid (Ahti 2000).

Morphologically it is similar to C. cristatella Tuckerman (1858: 428), an endemic species of eastern North America (Hammer 2001), that differs by the presence of stereome (Vainio 1887) and by the production of barbatic and didymic acids (Moore 1968, Brodo et al. 2001).

According to Ahti (2000), C. gracilenta Tuckerman (1862: 395) and C. leporina Fries (1831: 243) also have no stereome and produce usnic acid. However, C. gracilenta differs from C. maculata by the formation of scyphy (Ahti 2000) and C. leporina by the evanescent primary squamules (Ahti 2000, 
Brodo et al. 2001). Moreover, these species have no maculate podetia.

Cladonia subminiata S. Stenroos (1989: 256) also possess a persistent primary thallus and produce usnic acid, but the medulla is entirely white and the podetia, which are rarely present, are strongly phyllopodial, smaller, with discontinuous cortex and with stereome.

ADDITIONAL SPECIMENS EXAMINED

— BRAZIL. State of Santa Catarina: Municipality of Santo Amaro da Imperatriz, Pico da Serra do
Tabuleiro, $27^{\circ} 49^{\prime} \mathrm{S}, 48^{\circ} 53^{\prime} \mathrm{W}, 1250 \mathrm{~m}, 13$ August 2011, A. M. Charnei et al. 326, 385, 387, 388, 389 (UPCB).

Cladonia paranaensis Charnei, Eliasaro and Gumboski, sp. nov. (Figures 3A-B)

MycoBank MB 807911

Differing from Cladonia peziziformis by the primary squamules lacerate to incised, 0.5-1.7 $\times 0.3-1.0 \mathrm{~mm}$, friable and by the podetial surface ecorticate without fissures or slits.
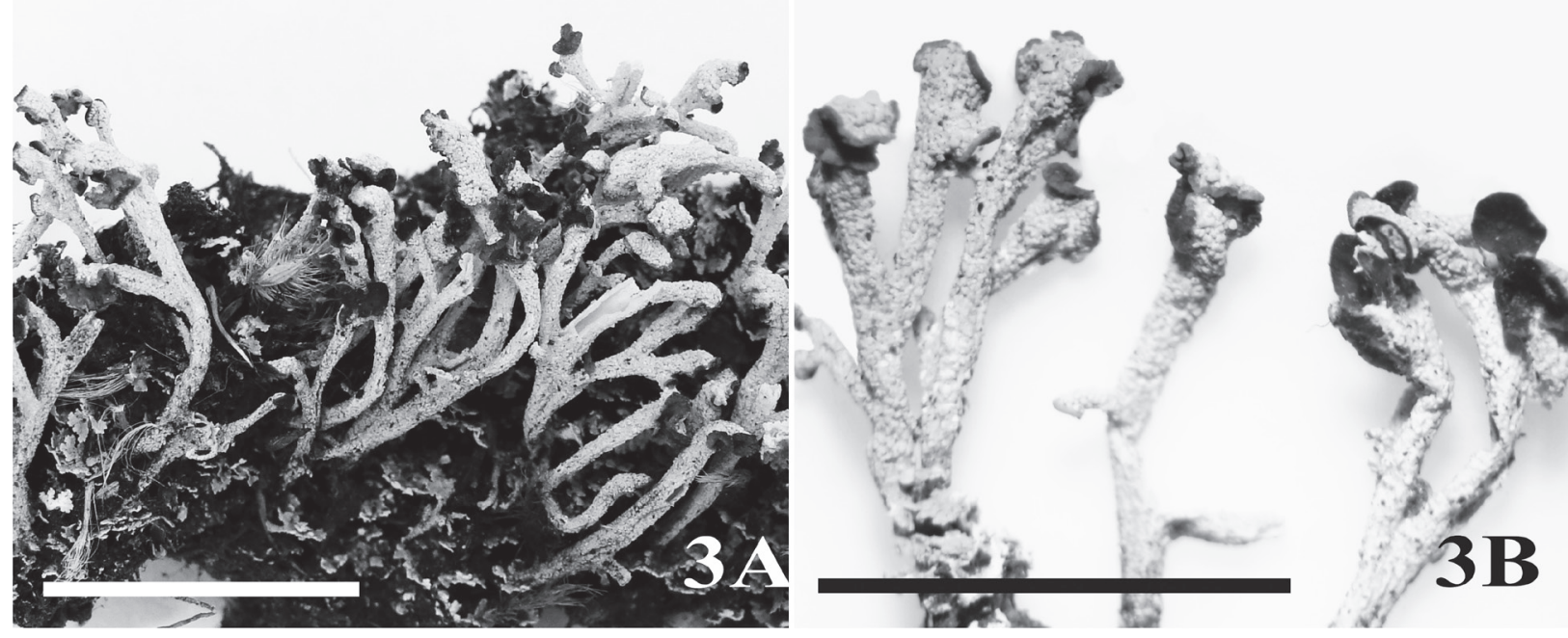

Figure 3 - C. paranaensis. A- General aspect. B- Detail of laterality of hymenial discs (A. M. Charnei et al. 141).

TYPE

- BRAZIL. State of Paraná: Municipality of Campina Grande do Sul, Serra do Ibitiraquire, Morro do Getúlio, 25¹4'S, 48 50’W, 1230 m, 06 July 2011, A. M. Charnei et al. 141 (Holotype UPCB).

\section{ETYMOLOGY}

The specific epithet is derived from the word "paraná", meaning from Paraná, a state in Southern Brazil.

DESCRIPTION

Primary thallus: persistent, consisting of lacerate to incised squamules, $0.5-1.7 \mathrm{~mm}$ long $\times 0.3-1.0$ $\mathrm{mm}$ wide, friable, imbricate, margins crenate, soredia and granules absent, without rhizines; upper surface corticate, green, smooth, slightly glossy, pruine absent; lower surface ecorticate, white or with brownish yellow spots, arachnoid, not veined; cortex 20-30 $\mu$ m thick; medulla 80-120 $\mu \mathrm{m}$ thick; pycnidia laminal, scarse, globose, black, mucilage and conidia absent. Secondary thallus: 0.3$1.4 \mathrm{~cm}$ tall, $0.4-0.8 \mathrm{~mm}$ thick at the base, thickening towards the apices, up to $1.5 \mathrm{~mm}$ thick at the apex, whitish grey, commonly simple to 2-3 branched, but rarely up to nine branches mostly in the upper half of podetia, imperforate, ascyphose, base not 
melanotic; surface entire, ecorticate, verruculose, esorediate, squamules scarce mainly at the base of podetia, up to $0.6 \mathrm{~mm}$ long, margins crenate; medulla (0-) 20-100 $\mu \mathrm{m}$ thick; stereome 100$250 \mu \mathrm{m}$ thick, hyaline, poorly delimited from the medulla; central canal papillate with longitudinal strands near the hymenial disks; hymenial disks beginning planes at the apex of podetium, but as they develop, due to further growth of one side of podetium, they become lateral and concave, brown, 0.5-1.8 mm in diameter; ascospores ellipsoid, 7-9 $\times$ $3 \mu \mathrm{m}$; pycnidia absent.

\section{CHEMISTRY}

Spot tests: K-, C-, KC-, UV-. TLC: fumarprotocetraric acid.

\section{ECOLOGY AND DISTRIBUTION}

Cladonia paranaensis is currently known only from the type locality, Morro do Getúlio, in the northeast part of the state of Paraná, and this hill much of the slopes and almost all the top was burned in 2007, and is currently covered by herbaceous vegetation. It occurs on soil, in well illuminated and exposed places and isolated from other species of Cladonia.

\section{REMARKS}

Cladonia paranaensis is a member of section Helopodium (sensu Ahti 2000) by the primary squamules persistent, ascyphose podetia, hymenial disks brown and by the production of fumarprotocetraric acid. Within this section, $C$. peziziformis (With.) J. R. Laundon (1984: 223) and C. solida Vain. (1890: 246), can have hymenial disks arranged laterally (Ahti, pers. comm.) as $C$. paranaensis (Figure 3B).

However, Cladonia peziziformis has primary squamules rounded, nearly circular, thick (220$320 \mu \mathrm{m}$ ), with margins smooth to slightly crenate and with granules (Ahti 2000, Wang et al. 2008, Burgaz and Ahti 2009), whereas C. parananensis has lacerate to incised squamules, thin (100-150 $\mu \mathrm{m})$ and very fragile (breaking easily when they are cut anatomically), with margins crenate without granules. These two species also differ in the podetial surface, in C. peziziformis it is corticate-areolate with longitudinal fissures that expose the central canal (as observed in the specimen G. Hatschbach 16428; MBM!), whereas in C. paranaensis it is ecorticate, entire, with no fissures or slits.

Cladonia solida differs from C. paranaensis in having corticate and solid podetia, rarely with hollow regions in the base as seen in the specimens occurring in the study area and similar to those reported by Vainio (1894), Ahti (2000) and Gumboski and Eliasaro (2012).

Cladonia furfuracea Vain. (1894: 375) also has podetia ecorticate and verrucose and contains fumarprotocetraric acid, but has most or all podetia scyphiforming and has isidioid squamules (Ahti 2000).

This species is, among the other species of Cladonia that occur in the Serra do Mar in South Brazil, the easiest Cladonia to identify due to its hymenial disks positioned laterally.

Cladonia quiririensis Charnei, Eliasaro and Gumboski, sp. nov. (Figures 4A-B)

MycoBank MB 807912

Differing from Cladonia polyscypha by absence of the scyphose podetia with the surface entirely ecorticate, and by the secondary squamules situated mainly in the apical region usually producing new podetia.

TYPE

- BRAZIL. State of Santa Catarina: Municipality of Garuva, Serra do Quiriri, 260.'56"S, 48 54'37’'W, 970 m, 07 May 2011, A. M. Charnei et al. 110 (Holotype UPCB).

ETYMOLOGY

The epithet "quiririensis" is derived from the TupiGuarani language word quiriri (= silence, peace) and refers to type locality. 


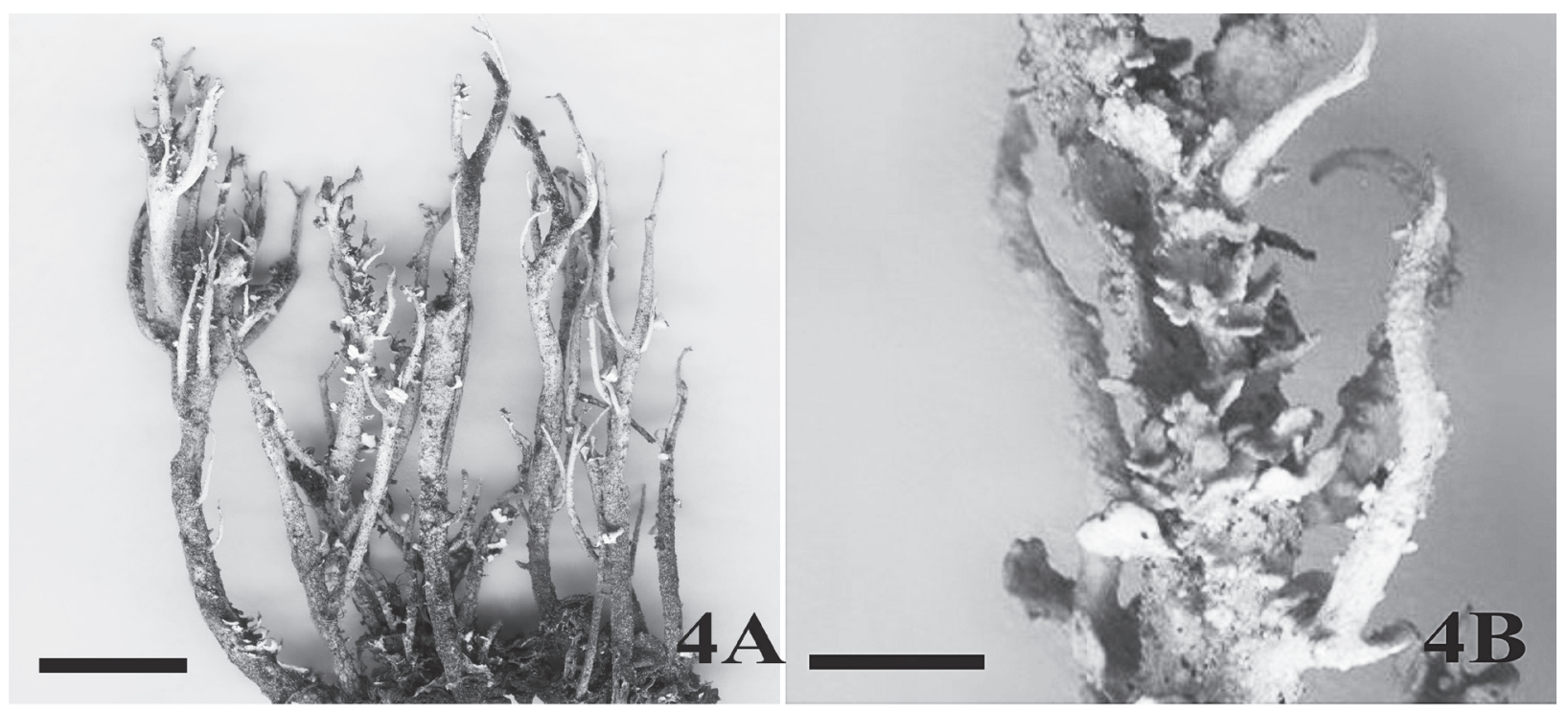

Figure 4 - C. quiririensis. A- General aspect. B- Detail of new podetia originated in the squamules of the podetia (A. M. Charnei et al. 110$)$. Scale bar $=1 \mathrm{~cm}($ except $3 \mathrm{~B}=1 \mathrm{~mm})$.

\section{DESCRIPTION}

Primary thallus: evanescent, consisting of lobed squamules, $1.0-3.0 \mathrm{~mm}$ long $\times$ 0.9-2.0 $\mathrm{mm}$ wide, soredia and granules absent, margins entire, without rhizines; upper surface corticate, greyish green, smooth, opaque, pruine absent; lower surface ecorticate, white with brownish spots in the base, arachnoid, not veined; cortex 30-50 $\mu \mathrm{m}$ thick; medulla 80-130 $\mu \mathrm{m}$ thick; pycnidia absent. Secondary thallus: $0.9-4.8 \mathrm{~cm}$ tall, $0.6-2.3 \mathrm{~mm}$ thick, whitish grey, slightly branched, branches mainly in the upper half of podetia, without clearly definite pattern, ranging from two to nine branches, tips subulate, base melanotic, imperforate; surface ecorticate, sorediate, soredia farinose generally falling and exposing the medulla and/or the stereome, granules absent, squamules laciniate, up to $1.2 \mathrm{~mm}$ long, located mainly in the apical region of the podetia, from where usually new podetia are formed; medulla 0-90 $\mu \mathrm{m}$ thick; stereome 110$240 \mu \mathrm{m}$ thick, brownish in the basal region, hyaline in the upper region; central canal grooved; hymenial disks absent; pycnidia apical, uncommon, dark brown, cylindrical to pyriform, mucilage hyaline; conidia slightly curved to falciform, 5-7 × $1 \mu \mathrm{m}$.
CHEMISTRY

Spot tests: K-, C-, KC-, UV-. TLC: fumarprotocetraric acid and traces of physodalic acid.

\section{ECOLOGY AND DISTRIBUTION}

Although collected in both states of Paraná and Santa Catarina, Cladonia quiririensis is a rare species that grows on soil, isolated from other species of Cladonia.

REMARKS

Cladonia quiririensis is characterized by the branched podetia with melanotic base and farinose soredia, entirely ecorticate, and by the secondary squamules situated mainly in the apical region and usually producing new podetia.

Morphologically C. quiririensis closely resembles C. polyscypha Ahti and L. Xavier (in Ahti et al. 1993: 61), but the latter species can be distinguished by the podetia simple to slightly branched, with apices mainly scyphose, with cortex at least in the basal region, sometimes the cortex reaching almost half of the podetia and by the secondary squamules scattered throughout the podetia (Ahti et al. 1993, Gumboski and Eliasaro 2012). 
Cladonia macilentoides Ahti and Fleig (in Fleig et al. 1995: 14) could also be mistaken for $C$. quiririensis, since in both the podetia are ascyphose and sorediate, and C. macilentoides sometimes has a melanotic base (Fleig et al. 1995, Ahti 2000) as in C. quiririensis. However, C. macilentoides has a podetia mainly simple to dichotomously branched, hymenial disks red and contains thamnolic acid. In the field, C. macilentoides (e.g. A. M. Charnei et al. 105, UPCB) and C. quiririensis grow together and they can be differentiated by the more branched podetia and by the formation of new podetia from the secondary squamules in the latter (Figure 4B).

Cladonia subradiata (Vain.) Sandstede. (1922: 230), a superficially similar and common species in Southern Brazil (Gumboski and Eliasaro 2012b), differs in having scyphose podetia without melanotic base.

\section{ADDITIONAL SPECIMENS EXAMINED}

- BRAZIL. State of Paraná: Municipality of Campina Grande do Sul, Serra da Graciosa, 24 August 1993, S. Eliasaro 1043 (UPCB). State of Santa Catarina: Municipality of Garuva, Serra do Quiriri, 2604'56'S, 4854'37'W, 970 m, 07 May 2011, A. M. Charnei et al. 107 (UPCB).

\section{ACKNOWLEDGMENTS}

We thank MSc. Alice Gerlach, MSc. Flávio Beilke, Vanessa Ariati and Victor de Freitas Batista for their assistance in the collecting. We thank the curator of MBM for the loan of specimens. We also thank FATMA (Fundação do Meio Ambiente) and IAP (Instituto Ambiental do Paraná) for the permission to collect, and Coordenadoria de Aperfeiçoamento de Pessoal de Nível Superior (CAPES) for granting a Mastership to Charnei.

\section{RESUMO}

Cladonia maculata, C. paranaensis e C. quiririensis são descritas como novas para a ciência. Estas espécies foram encontradas entre 900 a 1887 metros de altitude na Serra do Mar no Sul Brasil.
Palavras-chave: Líquen, Paraná, Santa Catarina, Serra do Mar, taxonomia.

\section{REFERENCES}

ALMEIDA FFM AND CARNEIRO CDR. 1998. Origem e Evolução da Serra do Mar. Rev Bras Geocienc 28(2): 135-150.

Aнті T. 2000. Cladoniaceae. Flora Neotropica Monograph 78: $1-363$.

Ahti T, Stenroos S ANd Xavier Filho L. 1993. The lichen family Cladoniaceae in Paraiba, Pernambuco and Sergipe, Northeast Brazil. Trop Bryol 7: 55-70.

BRodo IM, SHARNOFF S AND SHARNOFF S. 2001. Lichens of North America. Yale University Press, New Haven and London, $795 \mathrm{p}$.

Burgaz AR AND AHTI T. 2009. Cladoniaceae. Flora Liquenológica Ibérica. Vol. 4. Sociedad Española de Liquenología (SEL), Madrid, 111 p.

CHARNEI AM AND EliAsARo S. 2013. Verticillate Cladonia species (Lichenized Ascomycota) from high-altitude environments on the Serra do Mar Mountain in Southern Brazil. Hoehnea 40(1): 87-97.

Culberson CF AND Ammann K. 1979. Standardmethode zur dünnschichtchomatographie von flechtensubstanzen. Herzogia 5: 1-24.

ELIX JA AND ERNST-RUSSELL KD. 1993. A catalogue of standardized thin layer chromatographic data and biosynthetic relationships for lichen substances. $2^{\text {nd }}$ ed., Canberra: Australian National University.

FleIG M, AHTI T AND STENROOS S. 1995. A família Cladoniaceae (liquens) no Rio Grande do Sul, Brasil. Napaea 11: 1-29.

FRIES E. 1831. Lichenographia Europaea Reformata. Lundae, $486 \mathrm{p}$.

Gumboski EL AND Eliasaro S. 2012. Espécies de Cladonia P. Browne (Cladoniaceae, Ascomycota) do Supergrupo Cladonia em restingas e costões rochosos dos Estados do Paraná e de Santa Catarina, Brasil. Hoehnea 39(2): 315-337.

HAMMER S. 2001. Lateral growth patterns in the Cladoniaceae. Am J Bot 88(5): 788-796.

LAUNDON JR. 1984. The typification of Withering's neglected lichens. Lichenologist 16: 211-239.

MEYER GFW. 1825. Die Entwicklung, Metamorphose und Fortpflanzung der Flechten. Göttingen, 372 p.

MOORE BJ. 1968. The Macrolichen Flora of Florida. The Bryologist 71(3): 161-266.

NyLANDER W. 1874. Animadversiones circa Spruce Lichenes Amazonicos et Andinos. Flora 57: 70-73.

NYLANDER W. 1876. Lichens rapportées de l'île Campbell par M. Filhol. Compt Rend Hebd Séances Acad Sci 83: 87-90.

SANDSTEDE H. 1922. Die Cladonien des nordwestdeutschen Tieflandes und der deutschen Nordseeinseln. III, Nachträge. Abhandl. Naturwiss. Ver Bremen 25: 89-246.

SANTOS AR. 2004. A grande barreira da Serra do Mar: da trilha dos Tupiniquins à Rodovia dos Imigrantes. São Paulo, Ed. O Nome da Rosa, 122 p. 
STENROOS S. 1989. Taxonomic revision of the Cladonia miniata group. Ann Bot Fenn 26: 237-261.

TAYLOR CJ. 1967. The lichens of Ohio. Part I. Foliose lichens. The Ohio Biological Survey, The Ohio State University Press, Columbia.

TAYLOR CJ. 1968. The lichens of Ohio. Part II. Fruticose lichens. The Ohio Biological Survey, The Ohio State University Press, Columbia.

TUCKERMAN E. 1858. Supplement to an enumeration of North American lichens; Part first, containing brief diagnoses of new species. Amer Jour Sci and Arts 25: 422-430.

TUCKERMAN E. 1862. Observations on North American and other lichens (Continued from Vol. IV. p. 407). Proc Am Acad Arts Sci 5: 383-422.
VAINIO EA. 1887. Monographia Cladoniarum Universalis. I. Acta Soc Fauna Fl Fenn 4:1-509.

VAINIO EA. 1890. Etude sur la classification et la morphologie des lichens du Brésil, I. Acta Soc Fauna Fl Fenn 7: 1-247.

VAINIO EA. 1894. Monographia Cladoniarum Universalis. II. Acta Soc Fauna Fl Fenn 10:1-498.

Wang XY, Hur H, LeE Y M, Bae F, KoH Y J AND Hur JS. 2008. Cladonia peziziformis (Lichenized Ascomycota, Cladoniaceae) new to Korea. Mycobiology 36(3): 193-194. 